\title{
MEASURED STRATIGRAPHIC SECTION IN THE UPPER SCHRADER BLUFF FORMATION (LATE CAMPANIAN-MAASTRICHTIAN?), IVISHAK RIVER, ALASKA
}

David L. LePain, Marwan A. Wartes, Russell A. Kirkham, and Jacob R. Mongrain

Preliminary Interpretive Report 2021-3

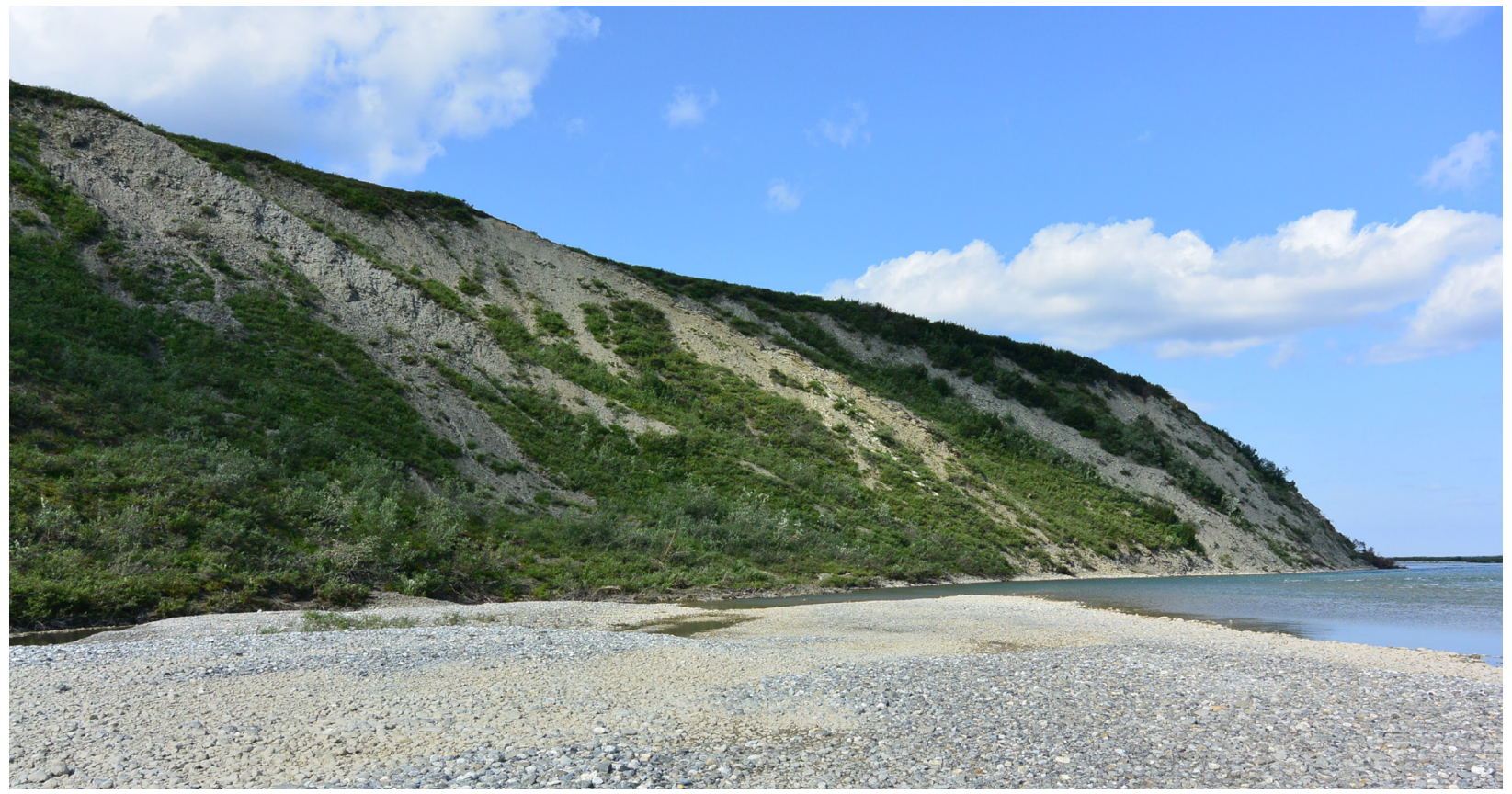

View toward the north-northwest showing the upper few hundred meters of the upper Schrader Bluff section addressed in this report. Note the resistant ridges trending obliquely down the slope toward the river, which correspond to the sandy upper parts of coarsening-upward shoreface-delta front parasequences.

This publication has not been reviewed for technical content or for conformity to the editorial standards for DGGS.

2021

STATE OF ALASKA

DEPARTMENT OF NATURAL RESOURCES

DIVISION OF GEOLOGICAL \& GEOPHYSICAL SURVEYS
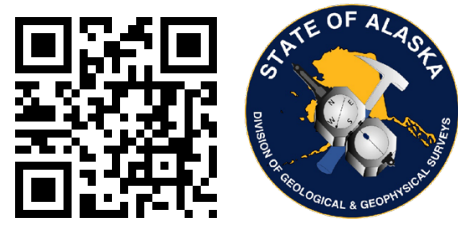
STATE OF ALASKA

Mike Dunleavy, Governor

DEPARTMENT OF NATURAL RESOURCES

Corri A. Feige, Commissioner

\section{DIVISION OF GEOLOGICAL \& GEOPHYSICAL SURVEYS}

Steve Masterman, State Geologist \& Director

Publications produced by the Division of Geological \& Geophysical Surveys are available to download from the DGGS website (dggs.alaska.gov). Publications on hard-copy or digital media can be examined or purchased in the Fairbanks office:

Alaska Division of Geological \& Geophysical Surveys (DGGS)

3354 College Road | Fairbanks, Alaska 99709-3707

Phone: 907.451.5010| Fax 907.451.5050

dggspubs@alaska.gov|dggs.alaska.gov

\section{DGGS publications are also available at:}

Alaska State Library, Historical

Collections \& Talking Book Center

395 Whittier Street

Juneau, Alaska 99801

Alaska Resource Library and

Information Services (ARLIS)

3150 C Street, Suite 100

Anchorage, Alaska 99503

\section{Suggested citation:}

LePain, D.L., Wartes, M.A., Kirkham, R.A., and Mongrain, J.R., 2021, Measured stratigraphic section in the upper Schrader Bluff Formation (Late Campanian-Maastrichtian?), Ivishak River, Alaska: Alaska Division of Geological \& Geophysical Surveys Preliminary Interpretive Report 2021-3, 11 p., 1 sheet. https://doi.org/10.14509/30693
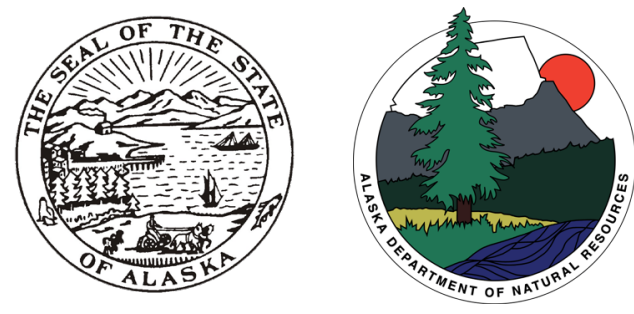


\title{
MEASURED STRATIGRAPHIC SECTION IN THE UPPER SCHRADER BLUFF FORMATION (LATE CAMPANIAN-MAASTRICHTIAN?), IVISHAK RIVER, ALASKA
}

\author{
David L. LePain', Marwan A. Wartes', Russell A. Kirkham², and Jacob R. Mongrain³
}

\section{INTRODUCTION}

The measured stratigraphic section presented in this report documents facies association stacking patterns in part of the upper Schrader Bluff Formation in an outcrop along the west side of the Ivishak River in the central North Slope of Alaska (fig. 1; sheet 1). The section is located on the north limb of the Kuparuk anticline approximately $8.4 \mathrm{~km}$ (5.2 mi) south-southeast of the Mobil Echooka Unit 1 well (fig. 2) and was measured over the course of three field seasons due to changes in the location of the active river channel. The composite measured section documents $834.5 \mathrm{~m}$ (2,737 ft) of upper Schrader Bluff stratigraphy. The base and top of the measured section do not correspond to the base and top of the upper Schrader Bluff. Despite extensive cover through fine-grained intervals, the outcrops addressed in this report represent the best exposures of the upper Schrader Bluff Formation known to the authors. For this reason, we view it as a reference section for the upper Schrader Bluff Formation.

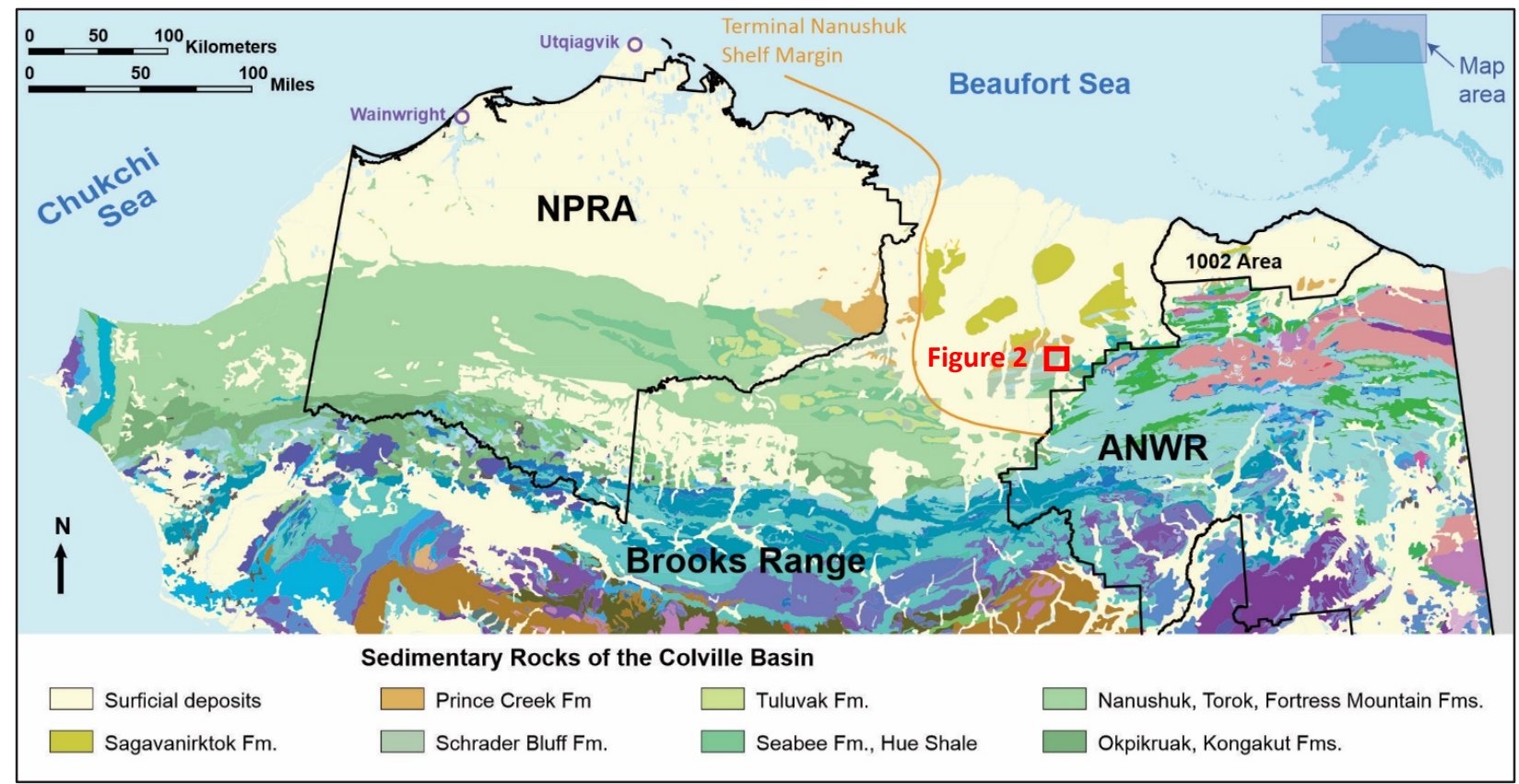

Figure 1. Regional geological map of northern Alaska. The red box shows the area included in figure 2. The pale yellow line east of the NPRA marks the approximate location of the progradational limit of the Albian-Cenomanian Nanushuk Formation, taken from Houseknecht (2019). Geologic map modified from Wilson and others (2015).

\footnotetext{
${ }_{1}^{1}$ Alaska Division of Geological \& Geophysical Surveys, 3354 College Road, Fairbanks, Alaska 99707: david.lepain@alaska.gov

${ }^{2}$ Alaska Division of Mining, Land and Water, 550 W. 7th Ave, Suite 1360, Anchorage, Alaska 99501

${ }^{3}$ NES-Fircroft, 150 N. Dairy Ashford, Houston, TX 77079
} 


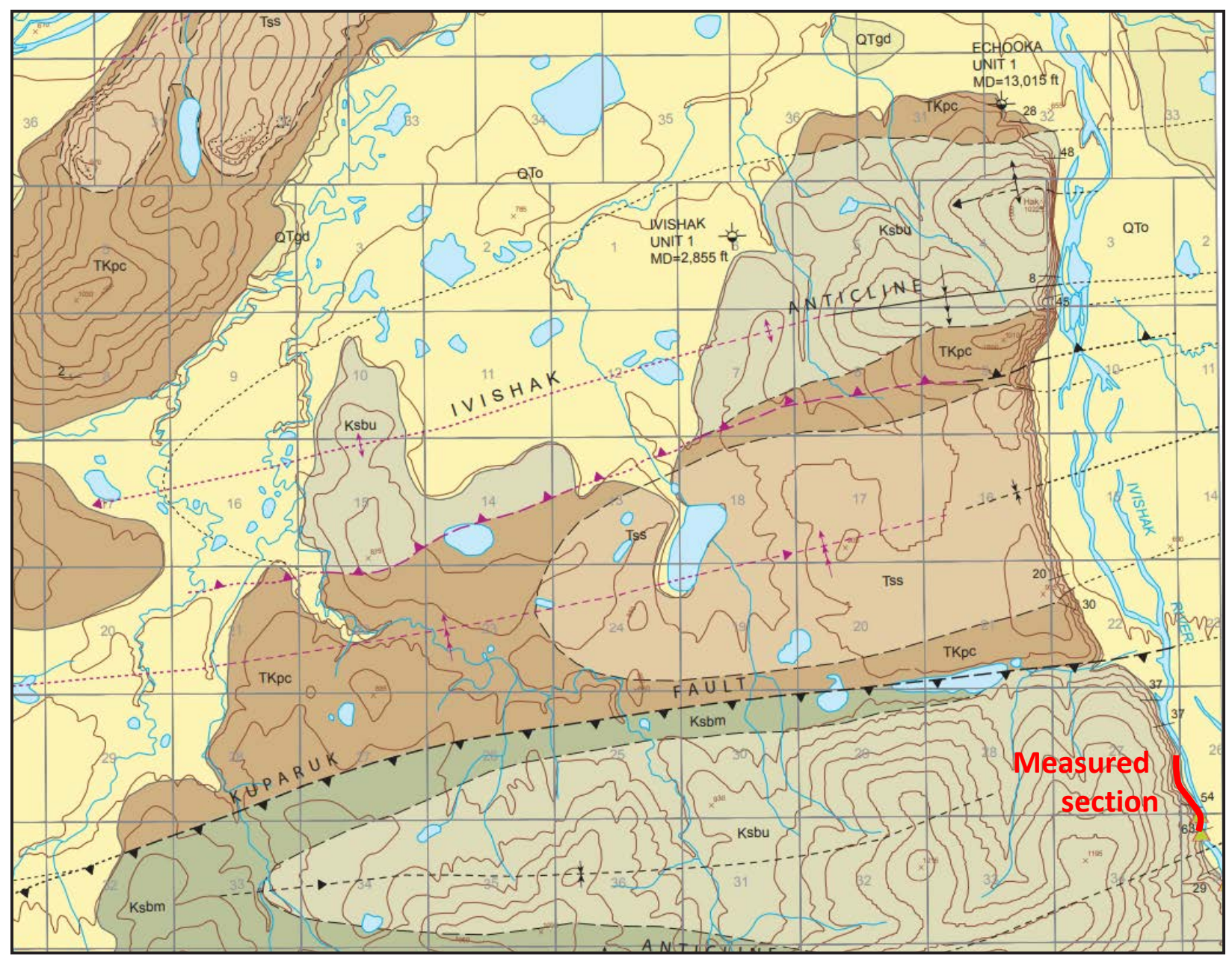

Figure 2. Bedrock geological map showing the location of the measured section (heavy red line) on the north limb of the Kuparuk anticline. Ksbm - middle Schrader Bluff Formation; Ksbu - upper Schrader Bluff Formation; TKpc - Prince Creek Formation; Tss - Sagwon Member of Sagavanirktok Formation. Map modified from Gillis and others (2014).

\section{REGIONAL SETTING AND STRATIGRAPHY}

The Schrader Bluff Formation is a thick, fossiliferous succession of interbedded clay shale, siltstone, sandstone, and bentonite deposited in a marine shelf environment (Mull and others, 2003). The unit is part of a genetic package that is regressive overall, consisting of coastal plain facies of the Prince Creek Formation, marine shelf deposits of the Schrader Bluff Formation, and slope and basin floor facies of the Canning Formation (fig. 3; Decker, 2007; Decker and others, 2009). On seismic sections the Prince Creek and Schrader Bluff correspond to topset reflectors throughout their depositional extents and the Canning Formation forms distinct clinoform and bottomset reflectors east of the progradational limit of the Nanushuk Formation (fig. 1).

The Schrader Bluff Formation was originally defined for exposures on the Anaktuvuk River at Schrader Bluff (Gryc and others, 1951). Whittington (1956) subdivided the unit into three formal members including, from the base upwards, the Rogers Creek, Barrow Trail, and Sentinel Hill. Mull and others 


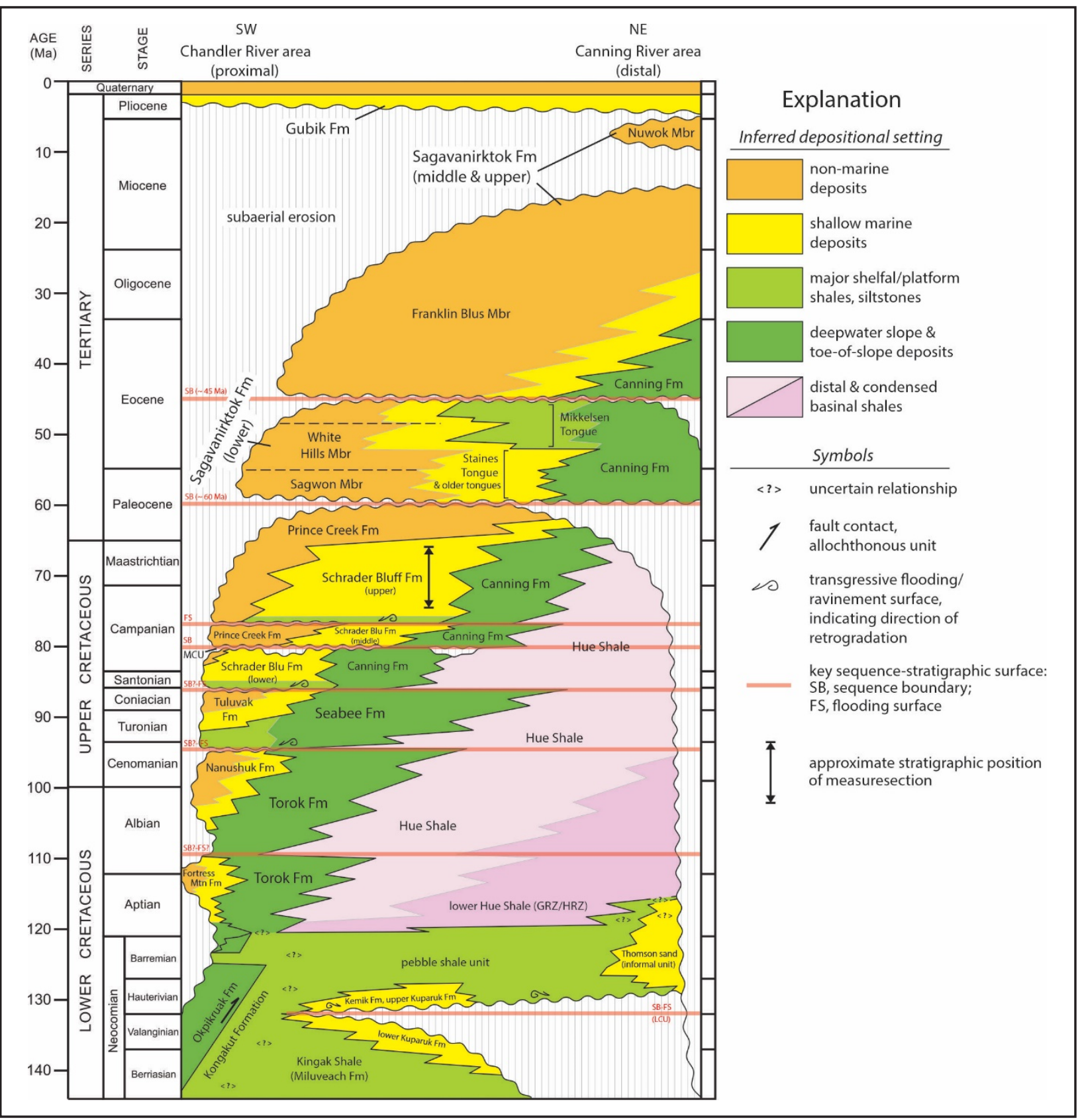

Figure 3. Generalized sequence stratigraphy of the Brookian sequence. Modified from Decker and others (2009). Available age control for strata in the measured section suggests a late Campanian age, but it is possible that the uppermost beds are Maastrichtian, as shown by the heavy black line with the double arrow. The Kingak Shale, Kuparuk Formation, Kemik Formation, pebble shale unit, and Thomsom sand comprise the Beaufortian sequence. MCU - mid-Campanian unconformity; LCU - Lower Cretaceous unconformity.

(2003) noted the Rogers Creek and Sentinel Hill Members were not lithologically distinct from each other and could only be recognized based on their positions relative to the more resistant Barrow Trail Member. These authors redefined the formation by abandoning the formal members and establishing informal lower, middle, and upper members. Subsequent workers have retained the former member nomenclature in the Umiat area, noting that the original subdivision was mappable at 1:63,360 scale and highlighted important stratigraphic and structural patterns (Herriott and others, 2018). 
Based on regional relationships, Mull and others (2003) recognized that the Prince Creek and Schrader Bluff Formations comprise a northeasterly prograding genetic succession of coastal plain and shelfal deposits. Decker (2007) developed a regional sequence stratigraphic framework for the Schrader Bluff Formation, noting that two widely correlatable internal surfaces provide an objective basis for subdividing the unit into lower, middle and upper members. A lower sequence boundary, referred to informally as the mid-Campanian unconformity (MCU), separates the lower and middle members, and an upper flooding surface separates the middle and upper members (Decker, 2007; fig.3). The easterly time-transgressive nature of the Schrader Bluff is clearly shown on regional wireline log cross-sections (Decker, 2007; Decker and others, 2009). An important outcome of this sequence stratigraphic framework is that the Schrader Bluff Formation in the type area in the Umiat Quadrangle corresponds entirely to the lower member (Decker, 2007), which is Santonian to Campanian in age (Mull and others, 2003). Exposures of the Schrader Bluff along an unnamed creek midway between the Sagavanirktok and Ivishak Rivers, informally named Sagashak Creek, are late Campanian based on available biostratigraphic control (LePain and others, 2008; Gillis and others, 2014) and correspond to the middle and upper informal members (Decker and others, 2009).

\section{AGE CONTROL FOR IVISHAK RIVER SECTION}

Three tephra samples collected in July 1999 from the original section were analyzed later that year via the ${ }^{40} \mathrm{Ar} /{ }^{39} \mathrm{Ar}$ method at the University of Alaska-Fairbanks Geochronology Laboratory. Two closely spaced samples at approximately $98 \mathrm{~m}$ and $99.6 \mathrm{~m}$ yielded whole rock isochron dates of $70.8 \mathrm{Ma} \pm 0.9$ $\mathrm{Ma}$ and 74.4 Ma $\pm 1.7 \mathrm{Ma}$, respectively (sheet 1 ). The tephra at $99.6 \mathrm{~m}$ is current ripple cross-laminated, indicating reworking by shallow marine currents, possibly explaining the older age from what is clearly a slightly younger bed. A more likely explanation is the older date results from excess argon in the sample. A tephra at approximately $755.5 \mathrm{~m}$ yielded a whole rock integrated ${ }^{40} \mathrm{Ar} /{ }^{39} \mathrm{Ar}$ date of $87.1 \mathrm{Ma} \pm 1.4 \mathrm{Ma}$, which conflicts with the tephras lower in the section and is clearly too old. Age spectra for these legacy ${ }^{40} \mathrm{Ar} /{ }^{39} \mathrm{Ar}$ samples are not available, limiting further interpretation of the problematic results. These dates were the best available age control at the time they were analyzed, but the lack of supporting data to allow critical evaluation of the results casts doubt on their validity.

An airfall-tephra deposit was sampled from approximately $755.5 \mathrm{~m}$ for $\mathrm{U}-\mathrm{Pb}$ geochronology in 2007 and analyzed in 2010. This sample is probably from the same volcanic ash seam as the upper ${ }^{40} \mathrm{Ar} /{ }^{39} \mathrm{Ar}$ sample mentioned in the previous paragraph. Zircon grains were separated and analyzed by Apatite to Zircon, Inc. via laser ablation inductively coupled plasma mass spectrometry (LA-ICPMS). Sample preparation and analytical methods followed those described in Bradley and O'Sullivan (2017). Thirty zircons were analyzed, yielding a range of dates (and uncertainties) that exceed the amount of dispersion expected for a single eruptive event (see Spencer and others, 2016; fig. 4; full isotope data and U-Pb dates are reported in appendix A). The slightly older tail of the date distribution is inferred to record xenocrystic and/or detrital mixing, which is evident in other airfall deposits (e.g. Bryan and others, 2004). In order to derive a statistically valid and geologically reasonable eruption age, a weighted mean was calculated using a subset of the youngest grains (fig. 4). Grain date selection criteria for this subset is modeled after the detrital zircon literature where a variety of techniques have been proposed to derive maximum depositional ages (MDAs) for strata based on the youngest grain or grains within a sample (Dickinson and Gehrels, 


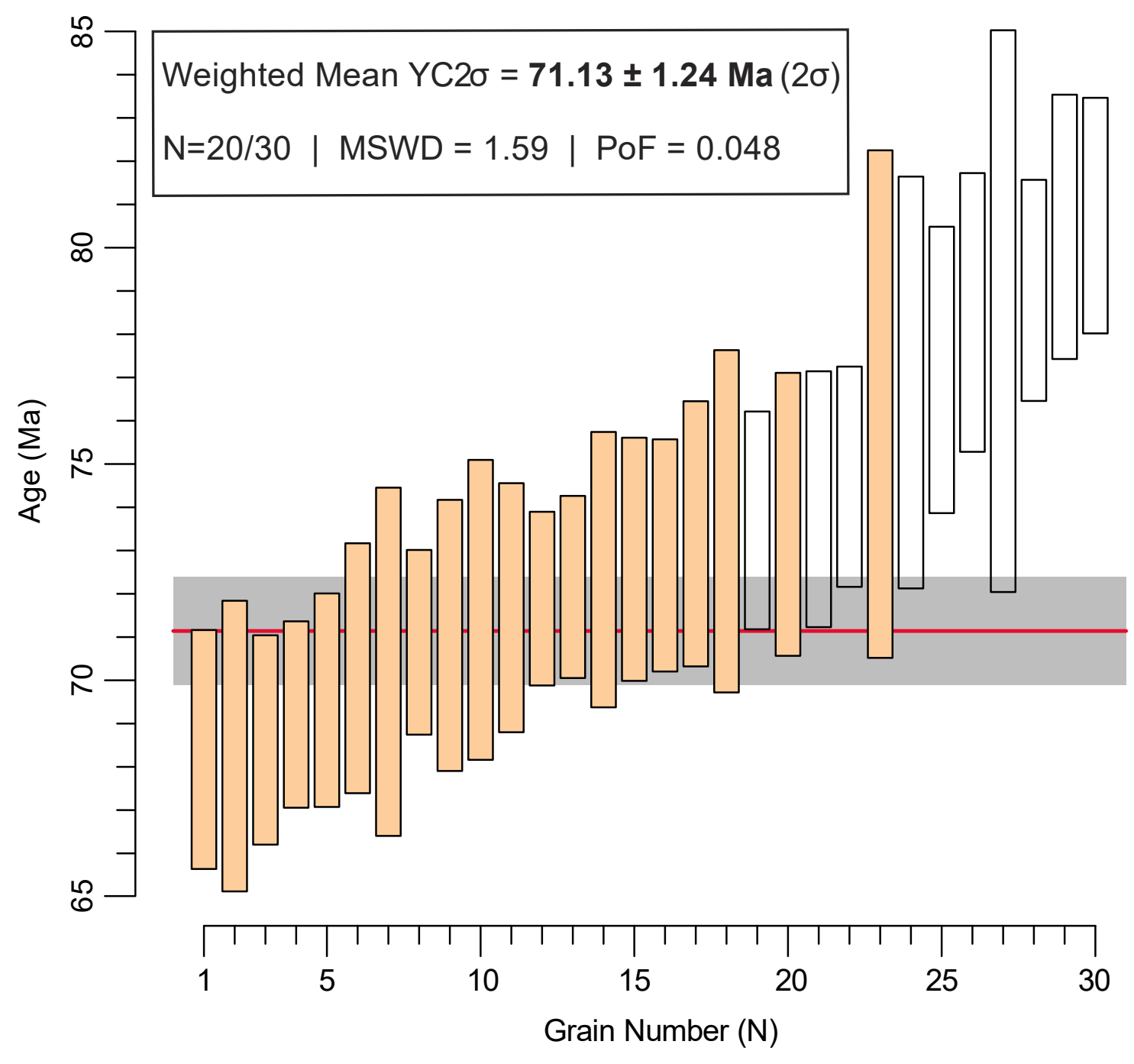

Figure 4. Ranked date plot of 30 zircon grains dated via U-Pb LA-ICPMS from sample 07DL040-30.8 (from 755.5 m in measured section). Vertical rectangles are individual dates and $2 \sigma$ analytical uncertainty. The red line indicates the weighted mean date of $71.13 \mathrm{Ma}$ calculated from the youngest cluster of 20 grains (show in tan) that overlapped one another within uncertainty. The grey shaded zone highlights the weighted mean age uncertainty of $\pm 1.2 \mathrm{Ma}$ that includes a propagated systematic component (see text). MSWD - mean square weighted deviation; $\mathrm{N}$ - sample size; PoF - probability of fit.

2009). In this case, we favored one of the most common methods for MDA calculation that selects a subpopulation based on the youngest cluster of three or more dates that overlap at $\pm 2 \sigma$ analytical uncertainty (see Coutts and others, 2019). A subpopulation of 20 out of 30 grains satisfied this selection criteria and resulted in a weighted mean age of $71.13 \pm 1.24 \mathrm{Ma}$ (fig. 4). The reported weighted mean age $2 \sigma$ uncertainty reflects both analytical uncertainty and an additional (generic) 1.5 percent $(2 \sigma)$ systematic uncertainty component as recommended by Coutts and others (2020; see also Horstwood and others, 2016).

The $\mathrm{U}-\mathrm{Pb}$ age is the first published robust radioisotopic age constraint for Upper Cretaceous rocks on the east-central North Slope. The U-Pb age is considered more reliable than the ${ }^{40} \mathrm{Ar} /{ }^{39} \mathrm{Ar}$ dates 
which are calculated from whole rock isochrons, rather than plateau ages. The ${ }^{40} \mathrm{Ar} /{ }^{39} \mathrm{Ar}$ date of $87.1 \mathrm{Ma}$ is deemed too old as it comes from the same zone, and most likely the same bed, in the upper part of the measured section as the $\mathrm{U}-\mathrm{Pb}$ sample. The youngest ${ }^{40} \mathrm{Ar} /{ }^{39} \mathrm{Ar}$ date of $70.8 \mathrm{Ma}$ is discounted as it is younger than the $\mathrm{U}-\mathrm{Pb}$ age, despite being from 657 meters lower in the section than the $\mathrm{U}-\mathrm{Pb}$ sample. In summary, the new $\mathrm{U}-\mathrm{Pb}$ age indicates the upper part of the measured section was deposited in the Early Maastrichtian. Given the thickness of underlying upper Schrader Bluff Formation, at least part of the unit likely ranges down into the Campanian. Additional support is provided by a badly damaged ammonite collected on the south limb of the Kuparuk anticline from similar stratigraphy, which was identified as a possible Asian variant of a Campanian pachydiscid (William Cobban, email communication with R. Blodgett). The absolute date and megafossil specimen are consistent with a late Campanian to Maastrichtian age assignment for nearby outcrops that are based principally on palynology and microfossils (Molenaar and others, 1984; Frederiksen and others, 1998; LePain and others, 2008; Gillis and others, 2014; Mull, unpublished data). As noted, the measured section does not include the entire thickness of the upper Schrader Bluff in the area, and it is possible the youngest beds are upper Maastrichtian or lower Paleocene.

\section{DESCRIPTION OF MEASURED SECTION}

The stratigraphic organization of the composite measured section consists, in ascending order, of the upper part of a regressive succession (fig. 5A), a thick, poorly exposed transgressive succession (fig. 5B), and a complete, thick, poorly to well-exposed regressive succession (fig. 5C; sheet 1). The lower regressive package ( $0 \mathrm{~m}$ to $84.3 \mathrm{~m}$ ) consists of shoreface-delta front parasequences that define the upper part of a highstand systems tract (fig. 5A). Alternatively, an abrupt grain size increase at $44.4 \mathrm{~m}$ could mark the position of a lowstand sequence boundary, in which case the succession from this surface to $84.3 \mathrm{~m}$ represents shoreface-delta front parasequences comprising a thin lowstand systems tract. We have low confidence in this interpretation. The slight decrease in grain size at $84.3 \mathrm{~m}$ marks the base of a transgressive systems tract and the overlying highly bioturbated sandstones ( $84.3 \mathrm{~m}$ to $95.5 \mathrm{~m}$ ) record gradual abandonment of a delta lobe. Alternatively, the bioturbated sandstones from $84.3 \mathrm{~m}$ to $95.5 \mathrm{~m}$ belong to the underlying systems tract (highstand or lowstand, depending on the significance of the grainsize increase at $44.4 \mathrm{~m}$ ). The interval from $95.5 \mathrm{~m}$ to $581 \mathrm{~m}$ is poorly exposed and includes a lower retrogradational stack of muddy parasequences ( $95.5 \mathrm{~m}$ to $406 \mathrm{~m}$ ) and an upper covered interval (406 m to approximately $581 \mathrm{~m}$ ) inferred to consist largely of clay shales. A maximum flooding surface is inferred at, or near $495 \mathrm{~m}$, but its precise location is unknown owing to extensive vegetation cover (fig. 5B). By definition, the stratigraphy between the transgressive surface at $84.3 \mathrm{~m}$ and the maximum flooding surface comprises a transgressive systems tract. Discontinuous exposures of sandstone starting at $581 \mathrm{~m}$ and culminating in a moderately well exposed sandstone-rich package that extends to the top of the measured section at $834.5 \mathrm{~m}$ defines the upper part of a second highstand systems tract (fig. 5C), the base of which, by definition, is the maximum flooding surface near $495 \mathrm{~m}$. The succession from $84.3 \mathrm{~m}$ (or $44.4 \mathrm{~m}$ if the grain size increase represents an unconformity) to the top of the composite section represents a thick, seismic-scale third-order sequence. 


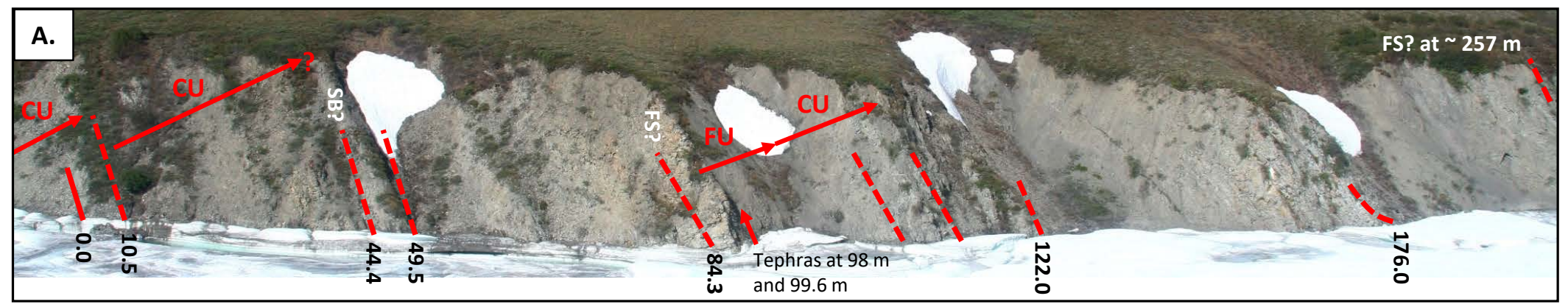

Figure 5. Photomosaic images illustrating the gross organization of the succession included in the measured

section addressed in this report. A. Low-altitude, oblique photomosaic showing the lower $257 \mathrm{~m}$ of the composite measured section. Additional Schrader Bluff section is present below the base of the measured section (toward the south). B. Photomosaic showing silty clay shale and siltstone grading upward toward the north to fine-grained sandstone capped by a flooding surface at $582.5 \mathrm{~m}$.

C. Oblique photo showing the top of the measured section at $834.5 \mathrm{~m}$, which corresponds to a marine flooding surface. Mud-dominated Schrader Bluff stratigraphy is concealed by tundra cover immediately up-section (toward the north) from the $834.5 \mathrm{~m}$ level. FS - flooding surface; $\mathrm{CU}$ - coarseningupward; SB - sequence boundary; MFS - maximum flooding surface. View in all photos is toward the west.
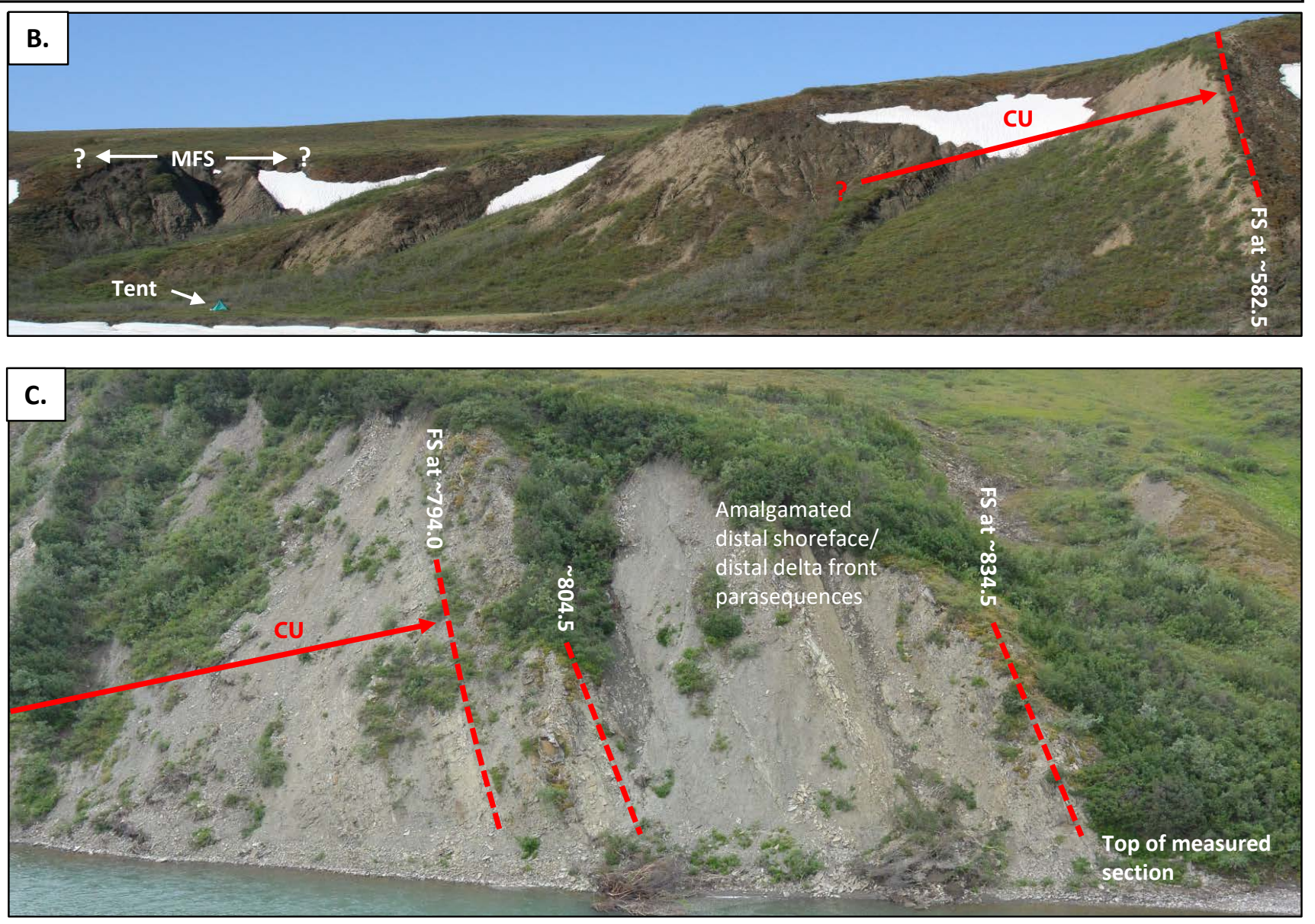


\section{CORRELATION TO MOBIL ECHOOKA UNIT 1 WELL}

We tentatively correlate the composite measured section with the upper Schrader Bluff Formation between approximately 5,700 feet and 2,650 feet (MD) in the Echooka Unit 1 well (fig. 6, red arrows on left side of well $\mathrm{log}$ ). The top and bottom of the measured section do not correspond to the top and bottom, respectively, of the upper part of Schrader Bluff Formation and, without better age control, other correlation possibilities cannot be ruled out. Further complicating correlation is the structural dip of the upper Schrader Bluff section penetrated in the Echooka Unit 1 well, which results in an apparent thickness estimated to be approximately 40 percent greater than the true stratigraphic thickness (based on measured dips in nearby surface outcrops reported by Gillis and others, 2014). Additional complications could result from differences that might be expected between locations spaced several kilometers apart in deltaic and delta-influenced shelf settings. One stretch of the coastline could be prograding while a nearby stretch is sediment starved and migrating landward (transgression). This situation could result in non-trivial differences in facies stacking patterns in the two areas, complicating attempts to correlate without robust age control.

\section{DESIGNATION AS REFERENCE SECTION FOR UPPER SCHRADER BLUFF FORMATION}

Given that the lower and upper parts of the measured section are relatively well exposed and that the gross sequence stratigraphic organization of the succession is clearly reflected by the succession of facies associations in outcrop and the distribution of covered section, we suggest the location serve as a reference section for the informally named upper Schrader Bluff Formation.

\section{ACKNOWLEDGMENTS}

The authors are indebted to Gil Mull for showing LePain the outcrop addressed in this report during the 1999 field season. Paul Decker (Oil Search Alaska) was instrumental in establishing the regional framework for the Schrader Bluff Formation and helping to integrate subsurface observations with surface outcrops. We thank Trystan Herriott (DGGS) for reviewing an early version of fig. 4 and discussions regarding sources of error in $\mathrm{U}-\mathrm{Pb}$ geochronology. Funding was provided by Chevron North America Exploration and Production Company, ConocoPhillips Alaska, Oil Search Alaska, U.S. Geological Survey, and the State of Alaska. We thank Ken Helmold (Alaska Division of Oil and Gas) for reviewing a draft of this report. 


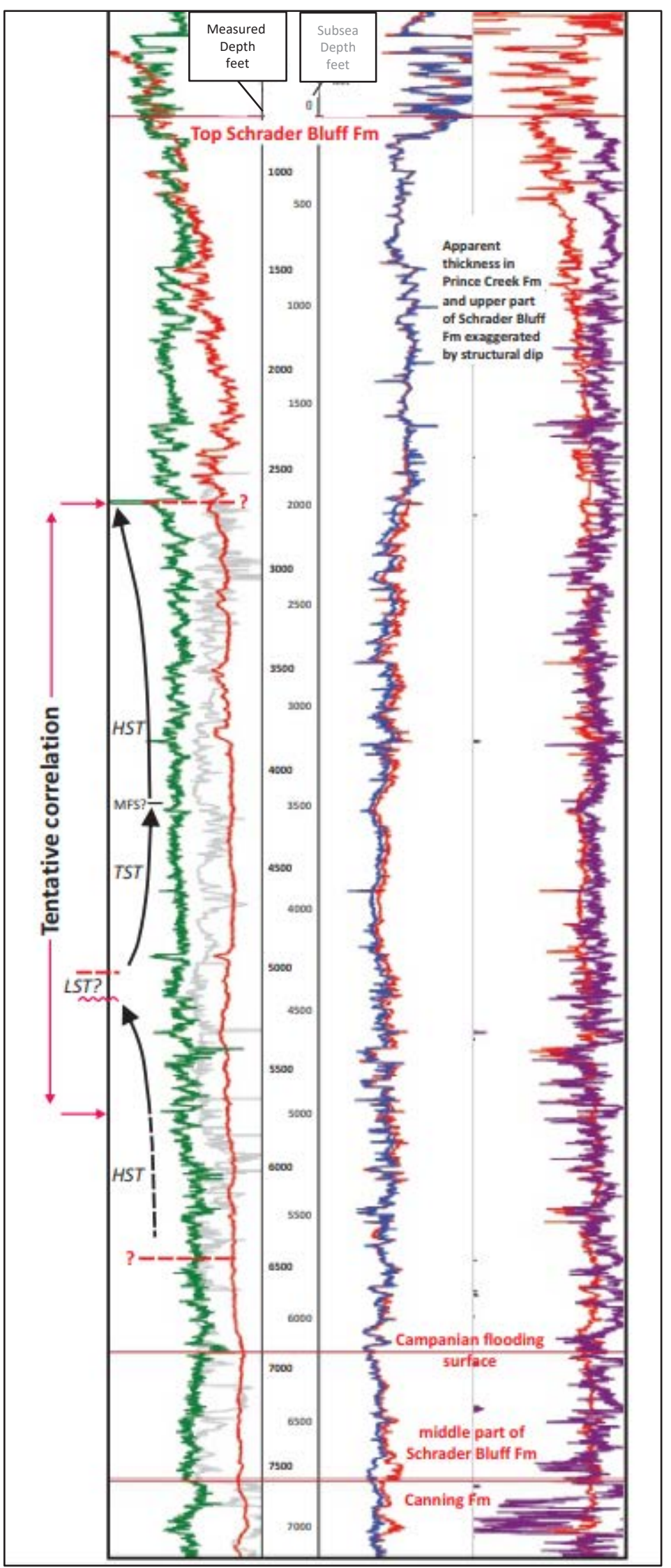

Figure 6. Mobil Echooka Unit 1 composite wireline log modified from Decker and others (2009). See figure 2 for location. The double red arrow to the left of the log shows our tentative correlation of the measured section to the well. 


\section{REFERENCES}

Bradley, D.C., and O'Sullivan, P.B., 2017, Detrital zircon geochronology of pre- and syncollisional strata, Acadian orogen, Maine Appalachians: Basin Research, v. 29, p. 571-590. https://doi.org/10.1111/bre.12188

Bryan, S.E., Allen, C.M. Holcombe, R.J., and Fielding, C.R., 2004, U-Pb zircon geochronology of Late Devonian to Early Carbonigerous extension-rlated silicic volcanism in the northern New England Fold Belt: Australian Journal of Earth Sciences, v. 51, issue 5, p. 645-664. https://doi.org/10.1111/j.1400-0952.2004.01079.x

Coutts, D.S., Matthews, W.A., Englert, R.G., Brooks, M.D., Bivin, M.-P., and Hubbard, S.M. 2020, Along-strike variations in sediment provenace within the Nanaimo basin reveal mechanism of forearc basin sediment influx events: Lithosphere, v. 12, no. 1, p. 180-197.

Coutts, D.S., Matthews, W.A., and Hubbard, S.M., 2019, Assessment of widely used methods to derive depositional ages from detrital zircon populations: Geoscience Frontiers, v. 10, p. 1,421-1,435. https://doi.org/10.1016/j. gsf.2018.11.002

Decker, P.L., 2007, Brookian sequence stratigraphic correlations, Umiat Field to Milne Point Field, west-central North Slope, Alaska: Alaska Division of Geological \& Geophysical Surveys Preliminary Interpretive Report 2007-2, 19 p., 1 sheet. https://doi.org/10.14509/15758

Decker, P.L., LePain, D.L., Wartes, M.A., Gillis, R.J., Mongrain, J.R., Kirkham, R.A., and Shellenbaum, D.P., 2009, Sedimentology, stratigraphy, and subsurface expression of upper Cretaceous strata in the Sagavanirktok River area, east-central North Slope, Alaska: Alaska Division of Geological \& Geophysical Surveys, 3 sheets. https://doi.org/10.14509/30156

Dickinson, W.R., and Gehrels, G.E., 2009, Use of U-Pb ages of detrital zircons to infer maximum depositional ages of strata: A test against a Colorado Plateau Mesozoic database: Earth and Planetary Science Letters, v. 288, p. 115-125. https://doi.org/10.1016/j.epsl.2009.09.013

Droser, M.L., and Bottjer, D.J., 1986, A semiquantitative field classification of ichnofabric: Journal of Sedimentary Petrology, v. 56, p. 558-559.

Frederiksen, N.O., Andrle, V.A.S., Sheehan, T.P., Ager, T.A., Collett, T.S., Fouch, T.D., Franczyk, K.J., and Johnsson, Mark, 1998, Palynological dating of Upper Cretaceous to middle Eocene strata in the Sagavanirktok and Canning Formations, North Slope of Alaska: U.S. Geological Survey Open-File Report 98-471, 51 p.

Gillis, R.J., Decker, P.L., Wartes, M.A., Loveland, A.M., and Hubbard, T.D., 2014, Geologic map of the south-central Sagavanirktok Quadrangle, North Slope, Alaska: Alaska Division of Geological \& Geophysical Surveys Report of Investigation 2014-4, 24 p., 2 sheets, scale 1:63,360. https://doi.org/10.14509/29138

Gryc, G., Patton, W.W., and Payne, T.G., 1951, Present Cretaceous stratigraphic nomenclature of northern Alaska: Washington Academy of Sciences Journal, v. 41, p. 159-167.

Herriott, T.M., Wartes, M.A., Decker, P.L., Gillis, R.J., Shellenbaum, D.P., Willingham, A.L., and Mauel, D.J., 2018, Geologic map of the Umiat-Gubik area, central North Slope, Alaska: Alaska Division of Geological \& Geophysical Surveys Report of Investigation 2018-6, 55 p., 1 sheet, scale 1:63,360. https://doi. org/10.14509/30099

Horstwood, M.S.A., Kosler, J., Gehrels, G., Jackson, S.E., McLean, N.M., Paton, C., Pearson, N.J., Sircombe, K.,Sylvester, P., Vermeesch, P., Bowring, J.F., Condon, D.J., and Schoene, B., 2016, Community-derived standards for LA-ICP-MS U-(Th)Pb geochronology - Uncertainty propagation, age interpretation and data reporting: Geostandards and Geoanalytical Research, v. 40, p. 311-332. 
Houseknecht, D.W., 2019, Petroleum systems framework of significant new oil discoveries in a giant Cretaceous (Aptian-Cenomanian) clinothem in Arctic Alaska: AAPG Bulletin, v. 103, p. 619-652. http://doi. org $/ 10.1306 / 08151817281$

LePain, D.L., Kirkham, R.A., Gillis, R.J., and Mongrain, J.R., 2008, Turonian-Campanian strata east of the Trans-Alaska Pipeline corridor, North Slope foothills, Alaska: Progress during the 2001-02 and 2007 field seasons, in Wartes, M.A., and Decker, P.L., eds., Preliminary results of recent geologic field investigations in the Brooks Range Foothills and North Slope, Alaska: Alaska Division of Geological \& Geophysical Surveys Preliminary Interpretive Report 2008-1G, p. 85-134. https://doi.org/10.14509/16090

Molenaar, C.M., Kirk, A.R., Magoon, L.B., and Huffman, A.C., 1984, Twenty-two measured sections of Cretaceous-lower Tertiary rocks, eastern North Slope, Alaska: U.S. Geological Survey Open-File Report 84-695, 21 p., 4 sheets.

Mull, C.G., Houseknecht, D.W., and Bird, K.J., 2003, Revised Cretaceous and Tertiary Stratigraphic Nomenclature in the Colville basin, northern Alaska: U.S. Geological Survey Professional Paper 1673.

Spencer, C.J., Kirkland, C.L., and Taylor, R.J.M., 2016, Strategies towards statistically robust interpretations of in situ U-Pb zircon geochronology: Geoscience Frontiers, v. 7, p. 581-589. https://doi.org/10.1016/j.gsf.2015.11.006

Taylor, A.M., and Goldring, R., 1993, Description and analysis of bioturbation and ichnofabric: Journal of the Geological Society of London, v. 150, p. 141-148.

Whittington, C.L., 1956, Revised stratigraphic nomenclature of Colville Group, in Gryc, G., and others, Mesozoic sequence in Colville River region, northern Alaska: American Association of Petroleum Geologist Bulletin, v.40, p. 244-253.

Wilson, F.H., Hults, C.P., Mull, C.G., and Karl, S.M., 2015, Geologic map of Alaska: U.S. Geological Survey Scientific Investigations Map 3340, 196 p., 2 sheets, scale 1:1,584,000. https://alaska.usgs.gov/science/geology/ state map/interactive map/AKgeologic map.html 